\title{
Design and Manufacture of a Dryer for Corn Grains, Ears and Cobs
}

\author{
Humberto Rodríguez-Fuentes ${ }^{1, a}$, Juan Arredondo-Valdez ${ }^{1, b}$, Wilgince Apollon ${ }^{1, c}$, Urbano Luna-Maldonado ${ }^{1,4}$, \\ Héctor Flores-Breceda ${ }^{1, e}$, Uziel Francisco Grajeda-González ${ }^{1, f}$, Alejandro Isabel Luna Maldonado ${ }^{1, g, *}$ \\ ${ }^{1}$ Autonomous University of Nuevo León, Faculty of Agronomy, Francisco Villa S / N, C.P. 66050 Col. Ex-Hacienda El Canadá, General \\ Escobedo, Nuevo León, México. \\ *Corresponding author
}

\begin{tabular}{|c|c|}
\hline A R T I C L E I N F O & A B S T R A C T \\
\hline $\begin{array}{l}\text { Keywords: } \\
\text { Dryer prototype } \\
\text { Corn } \\
\text { Moisture content } \\
\text { Modelling } \\
\text { Kerosene }\end{array}$ & $\begin{array}{l}\text { A corn dryer prototype was manufactured for Mexican small-scale farmers in order to avoid them } \\
\text { paying fines for corn with a high-moisture content when selling their corn on to stores. The dryer } \\
\text { comprised two large boxes perforated by round holes and containing stainless steel trays subjected to } \\
\text { a hot air temperature of } 45^{\circ} \mathrm{C} \text { within the batch. The accumulated grain in both boxes was } 200 \mathrm{~mm} \text { and } \\
\text { the airflow rate were } 0.56 \mathrm{~m}^{3} \mathrm{~s}^{-1} \text {. The corn ears layer was of } 80 \mathrm{~mm} \text { of depth in each of the boxes. The } \\
\text { airflow rate was } 0.34 \mathrm{~m}^{3} \mathrm{~s}^{-1} \text {. Within eight hours, we sampled corn grain in nine points of each box and } \\
\text { found that the mean corn grain moisture content was reduced from } 30.36 \% \text { to } 10.47 \% \text { for box } 1 \\
\text { whereas for box } 2 \text { it was reduced until } 14.72 \% \text {. The fuel consumption for drying was } 0.55 \mathrm{~kg} \mathrm{~h}^{-1} \text { of } \\
\text { kerosene. In Box1, the exponential regression model for corn grain moisture content had an } \mathrm{R}^{2} \text { of } \\
0.9143 \text { whereas Box } 2 \text { exponential regression model had an } \mathrm{R}^{2} \text { was of } 0.6642 \text {. In Box } 1 \text {, the } \\
\text { exponential regression model for corn ear moisture content had an } \mathrm{R}^{2} \text { of } 0.9616 \text { whereas Box } 2 \text { had an } \\
\mathrm{R}^{2} \text { was of } 0.9400 \text {. Both models for corn cob moisture content had an } \mathrm{R}^{2} \text { of } 0.9639 \text {. Two-layer corn } \\
\text { dryers can be used to harness gas or fuel energy to speed up drying for storage. }\end{array}$ \\
\hline
\end{tabular}

humberto.rodriguezfn@uanl.edu.mx(iD)https://orcid.org/0000-0001-6060-4146 Wilgince.apollon@uanl.edu.mx (i) https://orcid.org/0000-0002-3790-3807 e-hector.floresbrc@uanl.edu.mx $\checkmark$ alejandro.lunaml@uanl.edu.mx

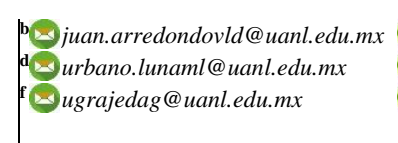
Dhttps://orcid.org/0000-0001-8448-8354
Dhtps://orcid.org/0000-0001-6195-2003
Dttps://orcid.org/0000-0003-2933-8550

(c) (1) (8) This work is licensed under Creative Commons Attribution 4.0 International License

\section{Introduction}

Mexican agriculture can be classified as modern and traditional. Two patterns of land holding prevail. Being one of them is the private property of the agricultural lands and the second one is composed of groups organized in small communities, namely ejidos, that holds federal lands.

In these sectors one of the most important crops is corn (Zea mays). In Mexico, corn grain production 27.7 million metric tons in 2017 (Zahniser, 2019, USDA, 2017). The corn harvested area and average yield are 7.5 million hectares and 3.47 tons per hectare, respectively. The states with the highest production of corn are Sinaloa, Tamaulipas, Veracruz, and Chiapas (SIAP, 2019).

The most important problem after corn harvesting with machine is the high moisture content in the corn grain and during grain storage the molds grow rapidly when the air has a high relative humidity and aflatoxin can reduce the quality and marketability of corn (Espinoza \& Ross, 2003; Munkvold et al., 2019). Optimal quality of corn depends on its use (Paulsen et al., 2019). Moreover, corn growers in the modern and traditional sectors in areas of humid climates have difficulty to sell their grain because of a high moisture content between $22-30 \%$ at the time of harvest
(Caro- Greiffenstein, 1998). The maximum moisture content of corn grains for storage varies between of $13.00 \%$ and $15.50 \%$ for less 6 months and more than 6 months, respectively; in other hand, storage corn ear moisture content varies between $12.4 \%$ and $15.1 \%$ (World-Grain, 2021; Hellevang, 1998; Yadav et al., 2019). If the corn growers do not have dryers and they want to sell their corn grains, they must pay fines to the storage companies.

Mathematical models to analyze have been developed to analyze conventional and newly developed drying methods (Thompson, 1968). Midilli model was used to predict the drying of grains at different air temperatures and found that at higher temperatures above $100{ }^{\circ} \mathrm{C}$, the isosteric desorption also increased (Coradi et al., 2015). A mathematical model was developed with the general form of the solution to the diffusion equation to predict the drying (Sharaf-Eldeen et al, 1980).

There are several researchers working on novel developments of corn dryers using kerosene as energy. A kerosene-fired batch dryer, which recorded an average fuel consumption rate of $2 \mathrm{~L} \mathrm{~h}^{-1}$ (Ozuma \& Olowonibi, 2012). A modified batch type dryer for rice grain was developed 
in Japan (Kalamphastra, 1995). The grain dryer using farinfrared radiation reduced the electricity and kerosene (Hidaka et al., 2004). It was also developed a low-cost mobile flash dryer for rice grain in Phillipines. It was found that the drying rate $\left(0.03 \mathrm{~kg}\right.$ moisture $\left.\mathrm{min}^{-1}\right)$ was maximum at $70^{\circ} \mathrm{C}$ of air temperature and $40 \mathrm{~m}^{3} \mathrm{~min}^{-1}$ of airflow rate (Bulaong et al., 1996). It is also important to research about behavior of moisture contents and temperatures in vertical dryers with two or more corn boxes.

The objective of this project was to design and manufacture a dryer prototype using upper and lower boxes as an experimental machine, which might be used for corn grain and corn ear drying.

\section{Materials and Methods}

The design parameters were chosen to provide to small farmers a suitable, cheap, and durable corn dryer. The description of the manufacturing components of the dryer of two boxes (Figure 1) is as follows:

\section{Frame and Body of the Dryer}

The frame was constructed using an angle with a thickness of $5 \mathrm{~mm}$ and $50 \mathrm{~mm}$ in width, and two grid structures were made using an angle whose thickness was $2.5 \mathrm{~mm}$ and $30 \mathrm{~mm}$ wide. Finally, they were joined using electric arc welding. A steel plate with a thickness of $1.2 \mathrm{~mm}$ was used to form the body of the dryer. The dimensions of the dryer were $530 \mathrm{~mm}$ (width) $\times 900 \mathrm{~mm}$ (length) $\times 1735$ $\mathrm{mm}$ (height).

\section{Box and Perforated Sheet}

The capacity of each box was $0.14 \mathrm{~m}^{3}(100 \mathrm{~kg})$ with a layer of corn of $310 \mathrm{~mm}$ and a free space of $150 \mathrm{~mm}$. The area of the perforated sheet is $4500 \mathrm{~cm}^{2}$. Each hole has an area of $36 \mathrm{~mm}^{2}$. The horizontal distance between successive perforations is $5 \mathrm{~mm}$ and the vertical distance is $4 \mathrm{~mm}$ (Figure 1). It also has a $254 \mathrm{~cm}^{2}$ gate to discharge the grain using a handle and a small shovel. This dryer has a mechanical system that allows the removal of the boxes as soon as the grain of corn is dry.

\section{Duct, Fan and Burner}

The conduit was $500 \mathrm{~mm}$ long and $390 \mathrm{~mm}$ in diameter. It was manufactured using a steel plate with a thickness of $1.2 \mathrm{~mm}$. This steel plate was processed in a roller machine to form a cylinder that was then joined using clamps and weld. A cylinder was welded to a support base (Figure 2).

Finally, a fan and burner model FB-386 from Yamamoto C. Ltd. was mounted to the duct and the duct was screwed to the dryer (Figure 3).

\section{Performance Test}

The objective of this test was to determine the time required to dry corn grain at a temperature of $45^{\circ} \mathrm{C}$ inside the dryer. $45^{\circ} \mathrm{C}$ would not affect the final quality of dried kernels (Akowuah et al., 2018). The time required to dry corn cobs was also determined. The corn grain was placed in the boxes at an average initial moisture content of $30.36 \%$. The amount of material was $40 \mathrm{~kg}$ in each of the boxes. The grain layer was almost $2000 \mathrm{~mm}$ since there was not enough material. The consumption of electrical energy was measured by installing a watt meter to the electric motor. The fan speed was measured using an electronic tachometer.
Table 1. Parameters of performance test when drying corn grains.

\begin{tabular}{l|cc}
\hline \multicolumn{1}{c|}{ Condition } & Box 1 & Box2 \\
\hline Outside Temperature $\left({ }^{\circ} \mathrm{C}\right)$ & 26.86 & 26.86 \\
Relative humidity $(\%)$ & 64.68 & 64.68 \\
Mass of corn grain $(\mathrm{kg})$ & 40 & 40 \\
Hot air temperature $\left({ }^{\circ} \mathrm{C}\right)$ & 45 & 45 \\
Drying time $(\mathrm{h})$ & 8 & 8 \\
Kerosene consumption $\left(\mathrm{kg} \mathrm{h}^{-1}\right)$ & 0.55 & 0.55 \\
Air flowrate $\left(\mathrm{m}^{3} \mathrm{~s}^{-1}\right)$ & 0.56 & 0.56 \\
Corn grain moisture content $(\%)$ & & \\
Initial & 30.36 & 30.36 \\
Final & 10.47 & 14.72 \\
Moisture drying rate $\left(\%\right.$ moisture $\left.\mathrm{h}^{-1}\right)$ & 2.44 & 1.91 \\
Electrical energy consumption $(\mathrm{kwh})$ & 2.13 & 2.13 \\
\hline
\end{tabular}

Table 2. Parameters of performance test when drying corn ear.

\begin{tabular}{l|cc}
\hline \multicolumn{1}{c|}{ Condition } & Box 1 & Box 2 \\
\hline Outside Temperature $\left({ }^{\circ} \mathrm{C}\right)$ & 17.83 & 17.83 \\
Relative humidity $(\%)$ & 92.16 & 92.16 \\
Mass of corn ear $(\mathrm{kg})$ & 20 & 20 \\
Hot air temperature $\left({ }^{\circ} \mathrm{C}\right)$ & 45 & 45 \\
Drying time $(\mathrm{h})$ & 10 & 10 \\
Kerosene consumption $\left(\mathrm{kg} \mathrm{h}^{-1}\right)$ & 0.91 & 0.91 \\
Air flowrate $\left(\mathrm{m}^{3} \mathrm{~s}^{-1}\right)$ & 0.34 & 0.34 \\
Corn ear grain moisture content $(\%)$ & & \\
Initial & 27.53 & 27.53 \\
Final & 11.55 & 12.90 \\
Moisture drying rate $\left(\%\right.$ moisture $\left.\mathrm{h}^{-1}\right)$ & 1.60 & 1.44 \\
Electrical energy consumption $(\mathrm{kwh})$ & 2.67 & 2.67 \\
\hline
\end{tabular}

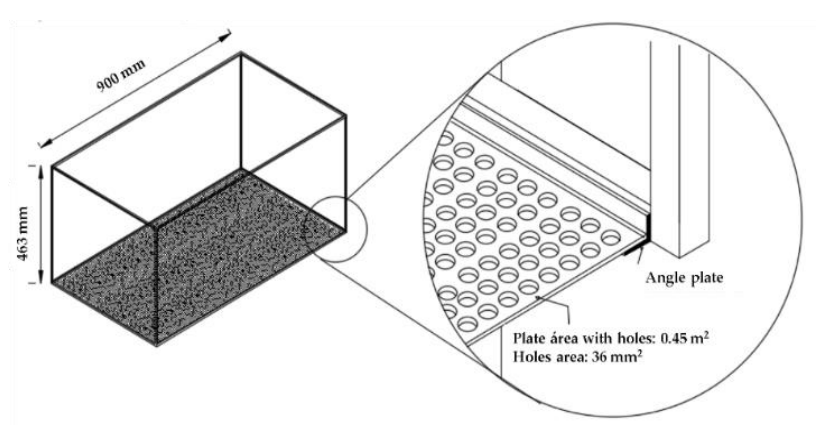

Figure 1. Round holes stainless steel sheet.

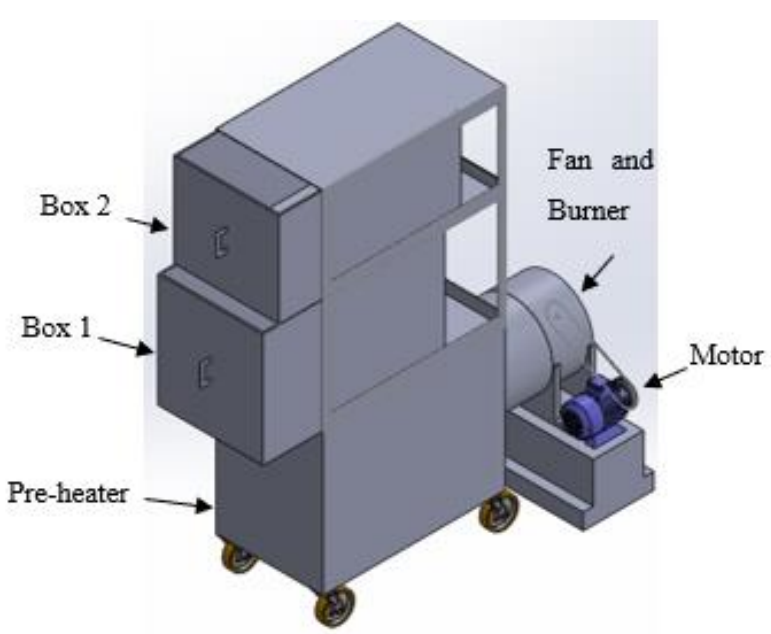

Figure 2. Conceptual design of corn dryer. 
The temperature of the grain was measured in each box by 3 thermocouples (Kawaso, Co.) located in the upper, middle, and bottom, to the center of both upper and lower boxes. The temperature data was recorded by a microprocessor and plotter. The moisture content of the grain was sampled at total 9 points with 3 repetitions from the upper, middle, and lower parts of the grain layer in each box. The average data of outdoor air conditions were obtained with the weather station.

A second test was carried out to dry ears of corn, which were placed in the boxes until forming an $80 \mathrm{~mm}$ layer. A procedure very similar to that of the test for drying grain was applied, except for the sampling method because the grain was removed from the cob. The amount of material placed in each box was only $20 \mathrm{~kg}$ because density of ears and unavailability of them. The initial content of the corn ear was $27.53 \%$.

Equations of Air Flowrate, Moisture Content and Drying Time

To estimate the air flowrate needed to dry the corn grain, the following equation was used:

$$
\mathrm{Q}=\frac{\mathrm{qz}}{3600 \rho \mathrm{C}\left(\mathrm{T}_{1-} \mathrm{T}_{\mathrm{o}}\right)}
$$

Where;

$\mathrm{Q}=$ Air flowrate, $\mathrm{m}^{3} \mathrm{~s}^{-1}$.

$\mathrm{q}=$ Caloric value of kerosene, $11.000 \mathrm{kcal} \mathrm{h}^{-1}$.

$\mathrm{z}=$ Fuel consumption, $\mathrm{kg} \mathrm{h}^{-1}$.

$\mathrm{C}=$ Specific heat, $0.25 \mathrm{kcal} \mathrm{kg}^{-1}{ }^{\circ} \mathrm{C}^{-1}$.

$\mathrm{T}_{1}=$ Mean temperature of dry air, ${ }^{\circ} \mathrm{C}$.

$\mathrm{T}_{0}=$ Mean atmospheric air temperature, ${ }^{\circ} \mathrm{C}$.

$p=$ air density, $1.2 \mathrm{~kg} \mathrm{~m}^{-3}$

To estimate the corn grain and ear moisture content, the following equation was used:

$$
\mathrm{H}_{\text {current }}=\mathrm{H}_{\text {storage }} \mathrm{e}^{\mathrm{rt}}
$$

Where;

$\mathrm{t}=$ Time, $\mathrm{h}$.

$\mathrm{e}=$ Napier number, 2.71828

$\mathrm{H}_{\text {storage }}=\quad$ Storage crop moisture content, $\%$.

$\mathrm{H}_{\text {current }}=\quad$ Current crop moisture content, $\%$.

$\mathrm{r}=$ Intrinsic rate of decrease of moisture content.

To estimate the drying time, the following equations was used:

$$
\mathrm{t}=\frac{\ln \frac{\mathrm{H}_{\text {storage }}}{\mathrm{H}_{\text {initial }}}}{\mathbf{r}}
$$

$\mathrm{H}_{\text {initial }}=$ İnitial crop moisture content, $\%$.

The predictive models were exponential regression models. To obtain the $\mathrm{H}_{\text {initial }}$ we linearized the exponential regression models and found $\mathrm{H}_{\text {initial }}$ value.

\section{Results}

\section{Performance Test}

The air flow required to dry the corn grain was $0.56 \mathrm{~m}^{3}$ $\mathrm{s}^{-1}$ and for corn cobs it was $0.34 \mathrm{~m}^{3} \mathrm{~s}^{-1}$ both at a speed of $1810 \mathrm{rpm}$. Tables 1 and 2 show the results of the performance test of the grain dryer and corn cob.

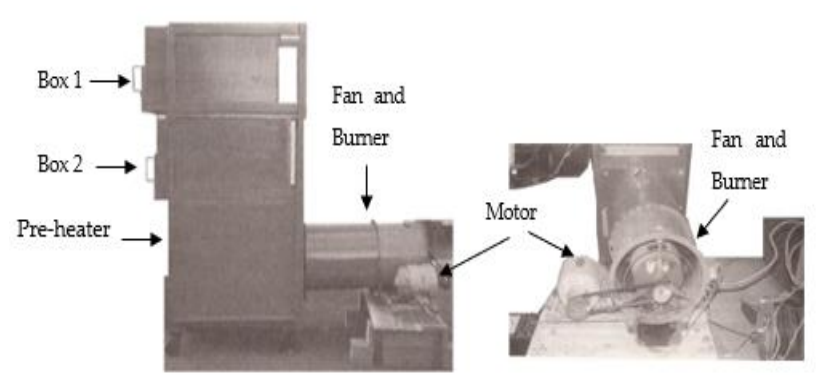

Figure 3. Dryer prototype(a), Duct, fan and burner(b)

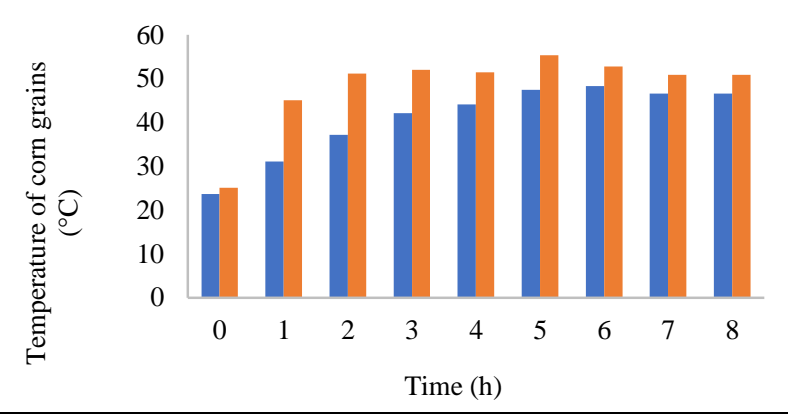

\begin{tabular}{l|rrrrrrrrr}
\hline Time(h) & 0 & 1 & 2 & 3 & 4 & 5 & 6 & 7 & 8 \\
\hline Box 1 & 23.6631 .1737 .1742 .1344 .1347 .47 & 48.3346 .63 & 46.6
\end{tabular}

\begin{tabular}{l|l} 
Box 2 & 25.1345 .0751 .2352 .0751 .5055 .3752 .8350 .9050 .91 \\
\hline
\end{tabular}

Figure 4. Temperatures versus time during the corn grain drying.

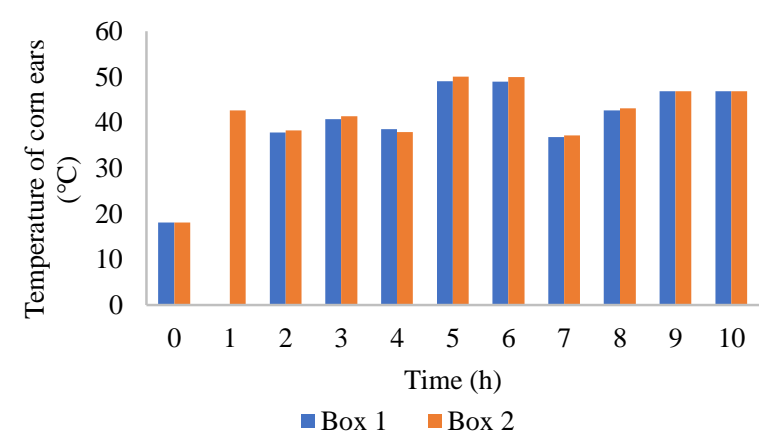

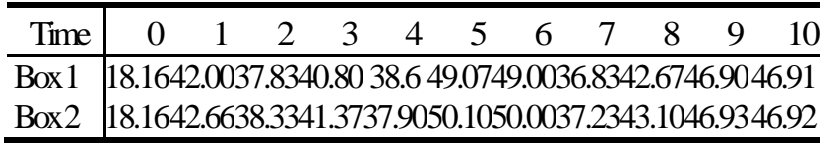

Figure 5. Temperatures versus time during the corn ears drying.

The function test has shown that the temperature difference between box 1 and 2 was $4.31^{\circ} \mathrm{C}$ for the case of corn grain while for corn cob it was 0.01 . The moisture content found at the end of the test showed a difference between boxes 1 and 2 of $4.27 \%$ in the case of corn grain and for grain removed from the corn cob this was $1.35 \%$.

\section{Temperature}

Figure 4 shows the temperatures in corn grain boxes during the corn drying performance tests. The highest temperatures of corn grains for storage were reached out at $6 \mathrm{~h}\left(48.33^{\circ} \mathrm{C}\right)$ and $5 \mathrm{~h}\left(52.83^{\circ} \mathrm{C}\right)$ for Box 1 and Box 2 , respectively. Figure 5 shows the changes in temperatures in corn ear during the corn drying performance tests. The highest temperature of corn earn for storage in both boxes were reached out at $5 \mathrm{~h}$ with $49.07^{\circ} \mathrm{C}$ for Box 1 and $50.10^{\circ} \mathrm{C}$ for Box 2. 


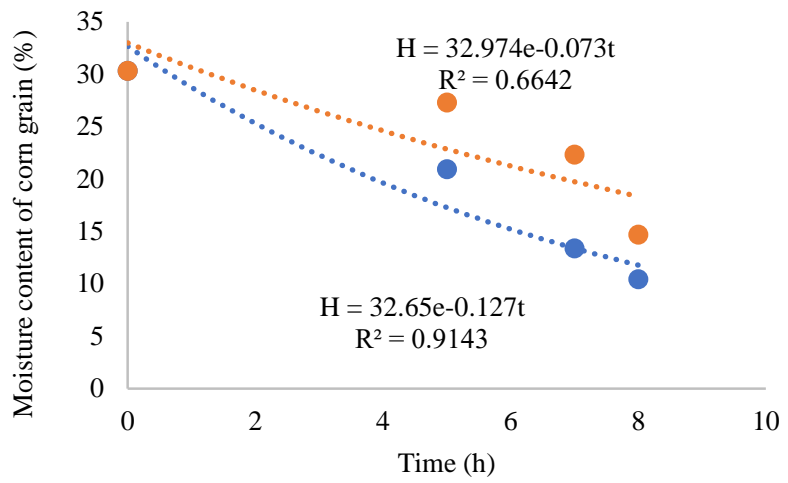

Box 1

\begin{tabular}{c|cccc}
\hline \multicolumn{5}{|c}{ Box 2 } \\
\hline Time $(\mathrm{h})$ & 0 & 5 & 7 & 8 \\
\hline Box 1 & 30.36 & 20.98 & 13.42 & 10.45 \\
Box 2 & 30.36 & 27.34 & 22.37 & 14.72 \\
\hline
\end{tabular}

Figure 6. Moisture content versus time during the corn grain drying.

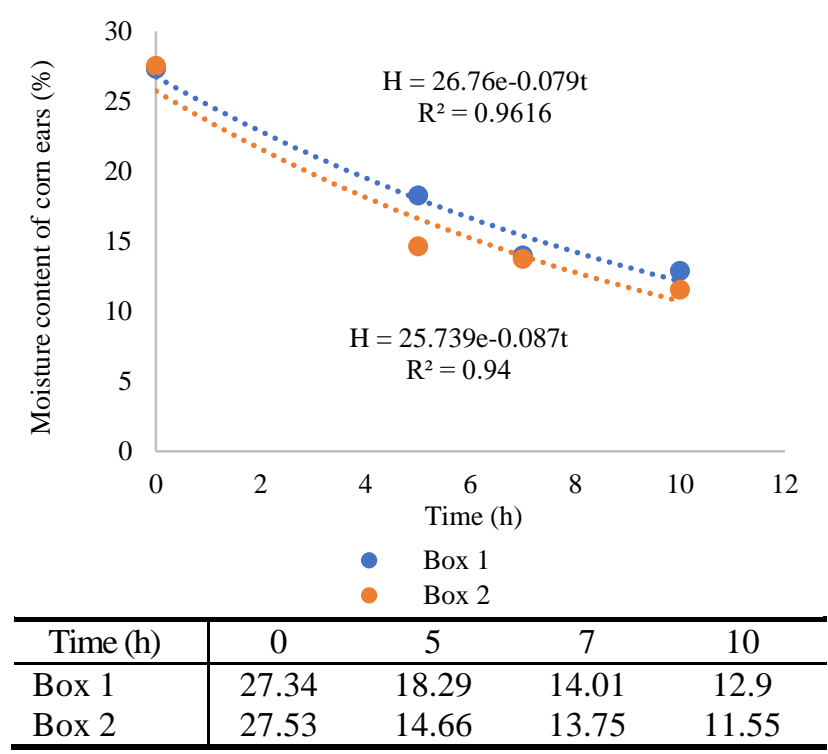

Figure 7. Moisture content versus time during the corn ears drying.

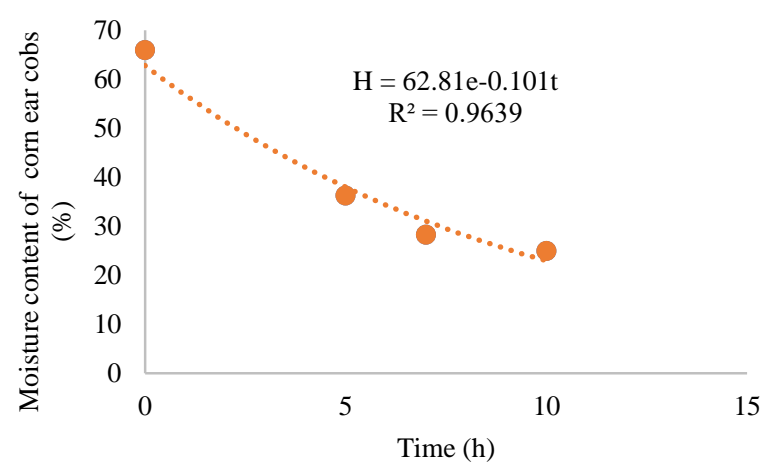

\begin{tabular}{l|cccc}
\hline Time $(\mathrm{h})$ & 0 & 5 & 7 & 10 \\
\hline Box 1 & 66 & 6.31 & 28.33 & 25 \\
Box 2 & 66 & 6.31 & 28.33 & 25 \\
\hline
\end{tabular}

Figure 8. Moisture content versus time during the corn cobs drying in both boxes.

\section{Moisture Content}

Corn grain moisture was tested for drying time 5, 7 and 8 hours, and corn cobs for 5,7 and 10 because laboratory time was limited.

Figure 6 shows the changes in moisture content in corn grain boxes during the corn drying performance tests. The moisture contents of corn grains for storage were reached out at $7 \mathrm{~h}$ (MC 13.42\%) and $8 \mathrm{~h}$ (MC 14.72\%) for Box 1 and Box 2 , respectively. Figure 7 shows the changes in moisture content in both corn ear and cob during the corn drying performance tests. The moisture contents of corn ear for storage in both boxes were reached out at $7 \mathrm{~h}$ with $14.01 \%$ for Box 1 and $13.75 \%$ for Box 2. In the case of moisture contents of corn cobs for storage reached. Moisture content varies between $12.4 \%$ and $15.1 \%$ for storage of corn cobs.

\section{Exponential Regression Models}

Figure 6 shows the regression models fitted in corn grain moisture in Box 1 and Box 2. In Box1, the exponential regression model for corn grain moisture content had an $\mathrm{R}^{2}$ of 0.9143 whereas Box 2 exponential regression model had an $\mathrm{R}^{2}$ was of 0.6642 . Figure 7 shows the regression models fitted in corn ear moisture in Box 1 and Box 2. In Box 1, the exponential regression model for corn ear moisture content had an $\mathrm{R}^{2}$ of 0.9616 whereas Box 2 exponential regression model had an $\mathrm{R}^{2}$ was of 0.9400 . Figure 8 shows the exponential regression models fitted in corn cob moisture in Box 1 and Box 2. Both exponential regression models for corn cob moisture content had an $\mathrm{R}^{2}$ of 0.9639 .

\section{Discussion}

The corn grain moisture content was reduced from $30.36 \%$ to $14.72 \%$ within 8 hours. The fuel consumption for drying was $0.55 \mathrm{~kg} \mathrm{~h}^{-1}$ of kerosene.

The corn ears moisture content was reduced from $27.53 \%$ to $\% 11.55 \%$ within $10 \mathrm{~h}$, while fuel consumption was $0.91 \mathrm{~kg} \mathrm{~h}^{-1}$ of kerosene.

The moisture contents of corn grains for storage were reached out at $5 \mathrm{~h}$ and $7 \mathrm{~h}$ for Box 1 and Box 2, respectively. The moisture contents of corn earn for storage in both boxes were reached out at $7 \mathrm{~h}$.

The highest temperatures of corn grains for storage were reached out at $6 \mathrm{~h}$ and $5 \mathrm{~h}$ for Box 1 and Box 2, respectively. The highest temperature of corn earn for storage in both boxes were reached out at $7 \mathrm{~h}$ (based on Figure 4).

In Box1, the exponential regression model for corn grain moisture content had an $\mathrm{R}^{2}$ of 0.9143 whereas Box 2 exponential regression model had an $\mathrm{R}^{2}$ was of 0.6642 . In Box1, the exponential regression model for corn ear moisture content had an $\mathrm{R}^{2}$ of 0.9616 whereas Box 2 regression model had an $\mathrm{R}^{2}$ was of 0.9400 . Both exponential regression models for corn cob moisture content had an $\mathrm{R}^{2}$ of 0.9639 .

\section{Conclusions}

Based on drying experiments with the dryer prototype of corn grain and ears the following can be concluded:

- Two-layer corn dryer prototype can be used to harness gas or fuel energy in order to speed up drying for storage. 
- The dryer batch kept a hot air temperature of $45^{\circ}$ during drying tests of corn grain and ears.

- The accumulated grain in both boxes was $200 \mathrm{~mm}$ and the airflow rate was $0.56 \mathrm{~m}^{3} \mathrm{~s}^{-1}$. The airflow rate was $0.34 \mathrm{~m} 3 \mathrm{~s}-1$. Within 8 hours, the corn grain moisture content was able to be reduced from $30.36 \%$ to $14.72 \%$. The fuel consumption for carrying out the drying was $0.55 \mathrm{~kg} \mathrm{~h}-1$ of kerosene. In lower box (Box1), the exponential regression model for corn grain moisture content had an $\mathrm{R}^{2}$ of 0.9143 whereas upper box (Box 2) had an $\mathrm{R}^{2}$ was of 0.6642 .

- The layer of corn ears was $80 \mathrm{~mm}$ in depth inside each of the boxes. Over 10 hours, results showed a reduction in moisture content of the corn ears of from $27.53 \%$ to $12.90 \%$, with a respective fuel consumption of $0.91 \mathrm{~kg} \mathrm{~h}-1$ of kerosene. When carried out over 10 hours, Box 1, had an $\mathrm{R}^{2}$ of 0.9616 whereas Box 2 had an $\mathrm{R}^{2}$ was of 0.94 .

- During drying test of ears both models for corn cob moisture content had an $\mathrm{R}^{2}$ of 0.9639 .

- It is desirable that the dryer be tested using different heights of the grain layers or corn cobs. It is also advisable to dry using different temperatures and quantities inside the dryer in order to establish best the relationship between them.

\section{Acknowledgments}

We thank to Scientific and Technological Research Support Program (PAICYT CT1519-21) from Universidad Autónoma de Nuevo León, Mexican Ministry of Education, Mexican Council for Science and Technology as well as Japanese International Cooperation Agency for their support.

\section{Author contributions}

AILM and HRF planned the experiments, interpreted the results, and made the write up of manuscript, JAV, HFB and WA interpreted the results, ULM made the write up of manuscript and UFGG statistically analyzed the data and made illustrations.

\section{References}

Akowuah JO, Maier D, Opit G, McNeill S, Amstrong P, Campabadal C, Obeng-Akrofi G. 2018. Drying temperature effect on kernel damage and viability of maize dried in a solar biomass hybrid dryer. Open Journal of Applied Sciences, 8(11): 506.
Bulaong MC, Dela Cruz RS, Andales SC. 1996. Commercialisation of a Mobile Flash Dryer for Farmer Cooperatives. In ACIAR Proceedings (pp. 262-267).

Caro- Greiffenstein A. 1998. Breves normas de control de calidad en granos almacenados. Proyecto de Asistencia Técnica en Poscosecha y Comercialización de Granos y Papas. GVP/ECU/065/NET. Documento de Campo (11).

Coradi PC, Milane LV, Dias CF, Baio FHR. 2015. Mathematical modeling of drying corn grains in different temperatures. Revista Brasileira de Milho e Sorgo, 14(2): 247-259.

Espinoza L, Ross J. 2003. Corn production handbook. Handbook. MP, 437.

Hellevang KJ. 1994. Grain drying. Extension Service. North Dakota State University. (Availabe at https://www.ag.ndsu. edu/graindrying)

Hidaka Y, Kubota K, Ichikawa T. 2004. Development of Grain Dryer Using Far-Infrared Radiation Yasuyuki. In 2004 ASAE Annual Meeting (p. 1). American Society of Agricultural and Biological Engineers.

Kalamphastra T. 1995. Modified Type Batch Dryer for Paddy. The Third Seminar on Farm Machinery for Developing Countries, Tsukuba, Japan. Pp (147-154).

Munkvold GP, Arias S, Taschl I, Gruber-Dorninger C. 2019. Mycotoxins in corn: occurrence, impacts, and management. In Corn (pp. 235-287). AACC International Press.

Ozumba IC, Olowonibi MM. 2012. Performance evaluation of NCAM kerosene-fired batch dryer. Journal of Agricultural Engineering and Technology, 20(2): 83-93.

Paulsen MR, Singh M, Singh V. 2019. Measurement and maintenance of corn quality. In Corn (pp. 165-211). AACC International Press.

SIAP, 2019. Siembras y Cosechas. Servicio de Información Agroalimentaria y Pesquera. México. (Availabe in https://www.gob.mx/siap/acciones-y-programas/produccionagricola-33119)

Sharaf-Eldeen YI, Blaisdell JL, Hamdy MY. 1980. A model for ear corn drying. Transactions of the [13] ASAE, 5(4): 12611265.

Thompson TL, Peart RM, Foster GH. 1968. Mathematical simulation of corn drying a new model.Transaction of the ASAE, 11(4): 582-586.

USDA, 2017. Mexico Corn: Adequate Reservoir Levels Benefitting Winter Corn. Foreign Agricultural Service (Available in https://ipad.fas.usda.gov/highlights/2017/03/ Mexico/index.htm).

WORLD-GRAIN 2021. Grain Operations: Grain storage management at your fingertips Available in https://www.world-grain.com/articles/14850-grainoperations-grain-storage-management-at-your-fingertips).

Yadav RS, Jha SK, Sinha JP, Aradwad P, Gaikwad N, Kumar AT, Samuel DVK. 2019. Cross-flow thin bed drying characteristics of corn (Zea mays) using continuous sample weight measurement. Indian Journal of Agricultural Sciences, 89(3): 458-462.

Zahniser S, López NFL, Motamed M, Vargas ZYS, Capehart T. 2019. The Growing Corn Economies of Mexico and the United States. US Department of Agriculture, Economic Research Service, FDS-19f-01. 